\title{
COMMUNICATIVE LANGUAGE TEACHING
}

\author{
CMammadova S., Azerbaijan State University of Economics, \\ Baku, Azerbaijan,azad.kerimov.59@mail.ru
}

\section{КОММУНИКАТИВНЫЙ МЕТОД ОБУЧЕНИЯ АНГЛИЙСКОМУ ЯЗЫКУ}

\section{(СМамедова С. T., Азербайджанский государственный экономический университет, г. Баку, Азербайджан, azad.kerimov.59@mail.ru}

Abstract. The purpose of this article is to provide an introduction to communicative language teaching (CLT) and to describe methodological principles that facilitate the language learning process. CLT furthermore takes a pragmatic or performance-based approach to learning. Its goal is to promote the development of real-life language skills by engaging the learner in contextualized, meaningful, and communicative-oriented learning tasks. CLT methodologies embrace an eclectic approach to teaching, which means they borrow teaching practices from a wide array of methods that have been found effective and that are in accordance with principles of learning as suggested by research findings in research in SLA and cognitive psychology. Its open-ended or principle-based approach allows for a great deal of flexibility, which makes it adaptable to many individual programmatic and learner needs and goals.

Аннотация. Основным принципом коммуникативного обучения языку является интерактивный подход. Коммуникативный метод возник еще в 1960-х годах. Лингвисты отмечали тогда предпочтение коммуникативного подхода изучению грамматических структур, т. к. можно знать грамматику языка, но быть не способным общаться на этом языке. Студенты должны уметь различать информацию в реальном контексте, обмениваться этой информацией, говорить на реальные темы и ситуации. Учитель должен стать аналитиком, советником и менеджером. Но как любой подход этот метод именно слабую сторону обеспечить студентов возможностью общения и сильное преимущество овладеть языковыми навыками непосредственно через общение.

Keywords: communication, English as foreign language, method, opportunity, planning, contemporary.

Ключевые слова: коммуникации, английский как иностранный язык, метод, возможности, планирование, современный.

It has been noticed that the goal of the most of the methods is to make the students able to communicate in the target language. But in the $1970 \mathrm{~s}$, the educators tried to find out whether they were going to meet the goal of the students in a right way or not. It had been observed that students were able to write and read the sentences in target language correctly. But when it came to communicate in the target language, they failed to do so. It made clear to the observer that to make the students able to communicate in the target language, it required more than mastering only the linguistic structures. It had been accepted by the educators that to be able to communicate in 
the target language, communicative competence is required with linguistic competence. There had been a shift from the linguistic structure centered approach to communicative approach in the late 1970 s and 80 s.

CLT is an approach to teach foreign or second language which emphasizes on communicative competence. It also emphasizes on interaction as a means to teach language. Communicative Language Teaching replaced the Situation Language Teaching which had been used to teach English as a second or foreign language. It had been considered as the major British approach. The focus of SLT approach was on to teach the basic structures of language. But in the 1960s, the educators realized that language taught on the basis of situational learning would have been of no use. Because to teach the meaning, carried out from the utterances was more required as it expressed the intentions of the speaker or writer.

Characteristics of CLT

1. It aims to make learners to attain communicative competence so the learners can use language accurately and appropriately.

2. The syllabus emphasizes the functional use of language. The syllabus is relying on the authentic materials. The tasks which are assigned to the learners have purposes and meanings.

3. In this approach, it is believed that communicative functions are more important rather than linguistic structures structural aspects of language, combine these into a more fully communicative view.

4. CLT approach provides the opportunities to communicate in the target language to the learners. It encourages teacher-student and student - student interaction. It helps to encourage the co-operative relationship among students. The teacher should give work in group or in pair which give opportunities to share the information among them. It also helps to promote the communication among them.

5. The teacher should create situations which help to promote communication. The teacher should teach them how language should be used in a social context. Teacher should give activities such as role play which help the learners to learn the language in social context.

6. Students should be given opportunities to listen to language as it is used in authentic communication.

\section{Role of the Teachers in the classroom}

The teachers are just the facilitators who facilitate the learning process. It is the responsibility of teachers to create such situations in which communication can take place among the students. They monitor the learning process. While using CLT approach in the class room, the teachers do not interrupt during the learning process to correct the errors of the learners. They just note the errors and correct it at a later point. The teachers give such types of activities which help to accelerate the communication process.

Communicative Language Teaching is an approach which provides opportunity to the learners to communicate in the target language.

Communicative language teaching is not a method. It is a guided idea. The purpose of Communicative Language Teaching is to help students produce authentic language and communicate with others. To produce authentic language does not mean developing speaking skills only. CLT integrates multiple skills, such as listening and writing to help students communicate, the teacher need to provide rich and authentic input.

A wide variety of materials have been used to support communicative approaches to language teaching. 
There are numerous textbooks designed to direct and support Communicative Language Teaching. Their tables of contents sometimes suggest a kind of grading and sequencing of language practice not unlike those found in structurally organized texts. Some of these are in fact written around a largely structural syllabus, with slight reformatting to justify their claims to be based on a communicative approach. Others, however, look very different from previous language teaching texts, for example, has none of the usual dialogues, drills, or sentence patterns and uses visual cues, taped cues, pictures, and sentence fragments to initiate conversation. consists of two different texts for pair work, each containing different information needed to enact role plays and carry out other pair activities. Texts written to support the likewise represent a departure from traditional textbook modes. A typical lesson consists of a theme, a task analysis for thematic development, a practice situation description stimulus comprehension questions, and paraphrase exercises.

Materials need to be authentic to reflect real-life situations and demands. One of the instructional practices promoted by communicative language teaching (CLT) is the extensive integration of authentic materials in the curriculum. Authentic materials refers to the use in teaching of texts, photographs, video selections, and other teaching resources that were not specially prepared for pedagogical purposes.

In other words, to develop learning resources around authentic materials, teachers must be prepared to spend a considerable amount of time locating suitable sources for materials and developing learning tasks that accompany the materials and scaffold the learning process.

\section{Challenges in Communicative Language Teaching}

CLT or a task-based approach is not a panacea to language teaching. There are numerous challenges to making communicative language teaching happen. These issues have to do with the choice of content, context, specific skill areas (e.g., vocabulary, grammar, etc.), and particular learning tasks that determine a curriculum.

These choices are tightly linked to questions about what it means to "know" a language, to be proficient in a language, and what communicative abilities entail. While the literature on language teaching has attempted to provide answers to such questions, there are no universally accepted standards. The proficiency and standards movements have attempted to provide some guidelines, but they often remain broad in learner performance descriptions. This ultimately makes assessment of individual learners' communicative ability challenging, and it essentially leaves judgment of learner progress up to the teachers. Communicative abilities cannot be simply categorized as speaking, listening, reading, or writing skills, as it was done in a traditional four skills approach. For example, when two people talk to each other, the process normally involves speaking and listening skills as well as active communicative strategies such as asking for clarification and adjusting language to make each other understood. The endeavor to teach languages in a way that encompasses all skills, based on an interactive view of language behavior, has posed many challenges on how to go about integrating the four skills effectively in a daily and long-term curriculum. The teaching of proficiency and communicative-based skills raises the question not only about content but also about the choice of learning tasks or best teaching practices. CLT does not promote one standardized method or curriculum, but is eclectic in its approach. Being eclectic means it promotes the best or most effective techniques or methodologies.

At the same time, the choice of techniques and learning tasks is not an arbitrary decision, but is firmly grounded in principles of learning as they are motivated by research in second language acquisition (SLA) and educational psychology. Learning what constitutes effective ways of learning and teaching initially requires intensive training and in the long run staying in touch with current SLA research findings.

As a last point, the quality of CLT also often depends on the quality of teaching materials. 


\section{References:}

1. Larsen-Freeman, D. (2000). Techniques and principles in language teaching. Oxford University.

2. Littlewood, W., \& William, L. (1981). Communicative language teaching: An introduction. Cambridge university press.

3. Richards, J. C., \& Rodgers, T. S. (2014). Approaches and methods in language teaching. Cambridge university press.

4. Brumfit, C. (1984). Communicative methodology in language teaching: The roles of fluency and accuracy. 129, 33. Cambridge: Cambridge University Press.

5. Feez, S. (1999). Text-based syllabus design. TESOL in Context, 9(1), 11.

6. Prabhu, N. S. (1987). 1987: Second language pedagogy. Oxford: Oxford University Press.

7. Skehan, P., Willis, E. J., \& Willis, D. (1996). Second language acquisition research and task-based instruction. Readings in Methodology, 13.

\section{Список литературы:} 2000.

1. Larsen-Freeman D. Techniques and principles in language teaching. Oxford University,

2. Littlewood W., William L. Communicative language teaching: An introduction. Cambridge university press, 1981.

3. Richards J. C., Rodgers T. S. Approaches and methods in language teaching. Cambridge university press, 2014.

4. Brumfit C. Communicative methodology in language teaching: The roles of fluency and accuracy. Cambridge : Cambridge University Press, 1984. Vol. 129. P. 33.

5. Feez S. et al. Text-based syllabus design // TESOL in Context. 1999. Vol. 9. №1. P. 11.

6. Prabhu N. S. 1987: Second language pedagogy. Oxford: Oxford University Press. 1987.

7. Skehan P., Willis E. J., Willis D. Second language acquisition research and task-based instruction //Readings in Methodology. 1996. Vol. 13.

Работа поступила

в редакцию 12.11.2019 2.
Принята к публикации

19.11.2019 2.

Ссылка для ијитирования:

Mammadova S. Communicative Language Teaching // Бюллетень науки и практики. 2019. T. 5. №12. C. 393-396. https://doi.org/10.33619/2414-2948/49/48

Cite as (APA):

Mammadova, S. (2019). Communicative Language Teaching. Bulletin of Science and Practice, 5(12), 393-396. https://doi.org/10.33619/2414-2948/49/48. 